OPEN ACCESS

Edited by: Gero Benckiser,

University of Giessen, Germany

Reviewed by:

Ming Wang

UC Riverside, USA

Stefanie P. Glaeser,

University of Giessen, Germany

*Correspondence:

Tong-Xian Liu

txliu@nwsuaf.edu.cn

†These authors have contributed equally to this work.

Received: 31 October 2016 Accepted: 16 March 2017

Published: 31 March 2017

Citation: Islam MN, Hasanuzzaman ATM, Zhang Z-F, Zhang $Y$ and LiU T-X (2017) High Level of Nitrogen Makes

Tomato Plants Releasing Less Volatiles and Attracting More Bemisia

tabaci (Hemiptera: Aleyrodidae).

Front. Plant Sci. 8:466.

doi: 10.3389/fpls.2017.00466

\section{High Level of Nitrogen Makes Tomato Plants Releasing Less Volatiles and Attracting More Bemisia tabaci (Hemiptera: Aleyrodidae)}

\author{
Md. Nazrul Islam 1,2,3†, Abu Tayeb Mohammad Hasanuzzaman 1,2,4t, Zhan-Feng Zhang,,2, \\ Yi Zhang ${ }^{1,2}$ and Tong-Xian Liu'1,2*
}

'State Key Laboratory of Crop Stress Biology for Arid Areas, Northwest A\&F University, Yangling, China, ${ }^{2}$ Key Laboratory of Integrated Pest Management on the Loess Plateau of Ministry of Agriculture, Northwest A\&F University, Yangling, China, ${ }^{3}$ Agrochemical and Environmental Research Division, Institute of food and radiation Biology, Atomic Energy Research Establishment, Dhaka, Bangladesh, ${ }^{4}$ Vertebrate Pest Division, Bangladesh Agricultural Research Institute, Gazipur, Bangladesh

Tomato (Solanum lycopersicum) production is seriously hampered by the infestation of the sweetpotato whitefly, Bemisia tabaci MEAM 1 (Middle East-Asia Minor 1). The infestation behavior of the whiteflies could be affected by the quantity of plant released volatile organic compounds (VOCs) related to nitrogen concentrations of the plant. In this study, we determined the infestation behavior of $B$. tabaci to the tomato plants that produced different levels of VOCs after application of different levels of nitrogen with a wind tunnel and an olfactometer. We also analyzed the VOCs released from nitrogentreated tomato plants using solid phase microextraction and gas chromatography-mass spectrometry. The results revealed that the production of eight VOCs $(\beta$-pinene, $(+)$ 4-carene, $\alpha$-terpinene, $p$-cymene, $\beta$-phellandrene, $\alpha$-copaene, $\beta$-caryophyllene, and $\alpha$-humulene) was reduced after the plants were treated with high levels of nitrogen. However, more whiteflies were attracted to the tomato plants treated with high levels of nitrogen than to the plants treated with normal or below normal levels of nitrogen. These results clearly indicated that nitrogen can change the quality and quantity of tomato plant volatile chemicals, which play important roles in $B$. tabaci host plant selection.

Keywords: Bemisia tabaci, tomato plant, nitrogen, plant volatiles, SPME, GC-MS

\section{INTRODUCTION}

Tomato, Solanum lycopersicum L., is an important vegetable in the world (Olaniyi et al., 2010; Bhowmik et al., 2012). There are many pests that cause both qualitative and quantitative losses of tomato (Lange and Bronson, 1981; Bari and Sarder, 1998). The sweetpotato whitefly, Bemisia tabaci (Genn.) (Hemiptera: Aleyrodoidea) is a major pest insect of vegetables, broadleaf field crops, and ornamentals in the tropics and sub-tropics of the world and in the protected environments of other areas (Liu, 2007). It is also considered one of the most important pests of tomato in the tropical and sub-tropical regions, causing heavy losses to crops by direct feeding and by transmitting geminiviruses (Toscano et al., 2002; Inbar and Gerling, 2008). 
Many abiotic factors have been shown to influence the emission of VOCs that affect the host preference of insect pests, their colonization and life histories. Nitrogen is an abiotic factor that could affect the emission of volatiles from crop plants and further affect the behaviors of insects (Berenbaum, 1995; Duffey and Stout, 1996; Veromann et al., 2013; Han et al., 2014). As tomato is a high valued commercial crop, tomato growers have a tendency to over-use fertilizers (Locascio et al., 1992). Many studies have showed that excessive nitrogen application above the standard recommendation often increases nitrogen leaching, causing soil and water pollution, and increasing cost (Zotarelli et al., 2007; Sieling and Kage, 2010; Engström et al., 2011). Most plant feeding insects have a capability to search for the plants with high nitrogen content (Southwood, 1973). Although nitrogen fertilization rarely affects herbivores directly, it can change or alter morphological, physiological, and biochemical characters of host plants and increase food quality for herbivores (Bernays, 1990; Simpson and Simpson, 1990). In general, nitrogen content of a host plant is considered as an indicator of nutritional quality and a factor influencing host plant selection by plant feeding insects (Mattson, 1980). Several studies showed that nitrogen application modifies plant biochemical contents and pest resistance against herbivores. For example, Han et al. (2014) found that sub-optimal nitrogen supply is not favorable for the survival and development of the tomato leafminer Tuta absoluta (Meyrick), and this may be due to an increase of leaf chemical defense system and decrease in leaf nutritional value. In another experiment, Chen et al. (2008) found that cotton plants with high nitrogen were preferred for oviposition by the female beet armyworm Spodoptera exigua (Hübner). Moreover, Bentz et al. (1995a,b) found that protein-nitrogen content was linearly increased in the leaves of the poinsettia (Euphorbia pulcherrima Willd. et Kl.) plant with increasing level of nitrogen application, and B. tabaci host selection was also linearly increased with increasing of nitrogen content in the plants.

The composition and levels of plant VOCs might be significantly affected by nitrogen fertilization (Chen et al., 2010) and consequently affecting their attractiveness to pests. The relation between the levels of fertilizer application and the emission of plant volatiles depends on the plant species either there can be a positive, negative or no relation between them. For instance, Jang et al. (2008) observed a reduction in jasmonic acid levels in rice plants when receiving high amounts of nitrogen in all three cultivars tested. Van Wassenhove et al. (1990) also confirmed that constitutive volatile chemicals extracted from celery significantly decreased with increasing of high levels of mineral and/or organic nitrogen fertilizers. On the other hand, Gouinguenè and Turlings (2002) found that a lower quantity of volatile compounds was released from unfertilized corn plants (Zea mays L. var. Delprim) compared to those receiving a complete nutrient solution. Therefore, the quantitative differences of VOCs released from different plant species can vary when plants receive different levels of fertilization. However, the effects of nitrogen on the pattern of release of VOCs might be system- or species-specific, and there might be a correlation between nitrogen application, volatiles production, and host plant preference of insect pests.

Chemical communication between host plants and herbivores mostly depends on the herbivore and plant species. It is also based on multiple compounds of the plants (Blight et al., 1997). It is well known that many herbivorous insect pests choose their hosts based on visual modalities (optical characteristics of plants), semiochemical stimuli (plant volatile compounds), or both (Bernays and Chapman, 1994a; Schoonhoven et al., 2005; Cook et al., 2007a,b; Hasanuzzaman et al., 2016). In a study, Bleeker et al. (2009) found that monoterpenes and sesquiterpenes released from tomato plants stimulated a response from receptors on the antennae of $B$. tabaci and these terpene volatiles played an important role in a free-choice bioassay. Ying et al. (2003) also demonstrated that B. tabaci can distinguish different types of host plant volatiles without any visual references.

Host plant volatiles can act as repellents or attractants for herbivores (Unsicker et al., 2009; Dicke and Baldwin, 2010; Mumm and Dicke, 2010). The defensive and nutritional chemistry of the plant leaf is one of the factors that influences host choice and fitness of herbivore insects (Bernays and Chapman, 1994b). Fertilization and allelochemicals can influence selection of hosts by pest population (Slosser et al., 2004; Chau et al., 2005; Germano et al., 2011). In this study, we hypothesized that nitrogen fertilization levels affect the abundance of $B$. tabaci, and that this potential modification is related to changes in volatile compound bouquets of the plants. We tested our hypothesis by applying different doses of a nitrogenous fertilizer to tomato plant and observed host preferences of the whiteflies through olfactory responses, and determined the plant volatiles emitted from the treated tomato plants. The results of this study deliver evidences that the composition of the volatile compounds from tomato plant is associated with the nitrogen fertilization and this influences host plant selection by $B$. tabaci.

\section{MATERIALS AND METHODS}

\section{Plant Growth and Fertilization}

Tomato plant [Solanum lycopersicum L., cv. 'Gan Liang Mao Fen $802 \mathrm{~F}_{1}$ ' seeds (Xian Qinshu Seeds Company Limited, Xian, Shaanxi, China)] were purchased from a local market. The seeds were sown in small plastic pots $(7 \mathrm{~cm} \times 7 \mathrm{~cm} \times 8 \mathrm{~cm})$ containing perlite as a plant-growing medium. The plants were grown inside insectaries where environmental conditions maintained at $25 \pm 1{ }^{\circ} \mathrm{C}$ with $60 \pm 5 \% \mathrm{RH}$ and 16:8 h L:D at a light intensity of 1400-1725 lux. All plants were nurtured in insect-proof mesh cages $(60 \mathrm{~cm} \times 60 \mathrm{~cm} \times 60 \mathrm{~cm})$.

We used four levels of nitrogen for growing tomato plants namely, $5 \mathrm{mM}\left(\mathrm{T}_{1}\right), 10 \mathrm{mM}\left(\mathrm{T}_{2}\right), 15 \mathrm{mM}\left(\mathrm{T}_{3}\right)$, and $20 \mathrm{mM}$ $\left(\mathrm{T}_{4}\right)$ nitrogen where $5 \mathrm{mM}$ was considered as a below normal level, $10 \mathrm{mM}$ a normal level, and $15 \mathrm{mM}$ and $20 \mathrm{mM}$ were as a high level. Wahle and Masiunas (2003) and Wang et al. (2007) reported that the growth and yield of tomato was highest at near about $10 \mathrm{mM}$ nitrogen levels but the tomato growth rate was limited with below $5 \mathrm{mM}$ of nitrogen solution. Nutrient 
solutions for growing tomato plants were prepared with $5 \mathrm{mM}$ nitrogen from a commercial fertilizer, 'Kang $\mathrm{Pu}$ Jin' with 20-2020 of $\mathrm{N}-\mathrm{P}_{2} \mathrm{O}_{5}-\mathrm{K}_{2} \mathrm{O}+\mathrm{Mg}+\mathrm{TE}$ (COMPO Expert GmbH, Krefeld, Germany), which was used as a standard control in all treatments. For other three treatments, i.e., $\mathrm{T}_{2}, \mathrm{~T}_{3}$, and $\mathrm{T}_{4}$, the source of additional nitrogen was urea (Sigma U 1250, purity > 99.5\%). The nutrient combination of above mentioned fertilizer was $\mathrm{N}-\mathrm{P}_{2} \mathrm{O}_{5}-\mathrm{K}_{2} \mathrm{O}$ (20\%-20\%-20\%), Mg (0.3\%) and other necessary trace elements, including $\mathrm{S}(0.8 \%), \mathrm{B}(0.01 \%)$, chelated $\mathrm{Cu}$ $(0.04 \%)$, chelated Fe $(0.1 \%)$, chelated $\mathrm{Mn}(0.1 \%)$, chelated $\mathrm{Zn}$ $(0.04 \%)$, and Mo $(0.003 \%)$. The $\mathrm{pH}$ of the nutrient solutions was corrected at 6.0-6.5 if needed to add concentrated $\mathrm{HCl}$ or $\mathrm{NaOH}$. The nutrient solutions were prepared with de-ionized water (Millipore, $\operatorname{Rios}^{\mathrm{TM}} 5$ ).

Different levels of nitrogen containing fertilizer solutions were applied to tomato plants following the technique of Stout et al. (1998) with slight modification. Tomato seeds were sown in the small plastic pots $(7 \mathrm{~cm} \times 7 \mathrm{~cm} \times 8 \mathrm{~cm})$ containing perlite as a plant-growing medium and watered with de-ionized water (Millipore, Rios $^{\mathrm{TM}}$ 5) up to 8 days after seed sowing. The plants were randomly assigned as $T_{1}, T_{2}, T_{3}$, and $T_{4}$ treatments for 5, 10, 15, and $20 \mathrm{mM}$ nitrogen, respectively. From 9th to 14th day, all plants were fertilized daily with $20 \mathrm{ml}$ of $5 \mathrm{mM}$ nitrogen prepared nutrient solution to avoid severe changes in the level of nitrogen applied to a plant. From days 15 to 20, all plants were fertilized daily with $20 \mathrm{ml}$ of $10 \mathrm{mM}$ nitrogen prepared nutrient solution except $\mathrm{T}_{1}$ treatment, which were fertilized daily with $5 \mathrm{mM}$ nitrogen prepared nutrient solution. From days 21 to completion of the experiment, $\mathrm{T}_{3}$ and $\mathrm{T}_{4}$ treatments were fertilized daily with $20 \mathrm{ml}$ of $15 \mathrm{mM}$ and $20 \mathrm{mM}$ nitrogen prepared nutrient solutions, respectively. At that time, $\mathrm{T}_{1}$ and $\mathrm{T}_{2}$ treatments were fertilized daily with $20 \mathrm{ml}$ of $5 \mathrm{mM}$ and $10 \mathrm{mM}$ nitrogen prepared nutrient solutions, respectively, as followed in previous fertilization. To avoid water stress, additional deionized water was added as necessary. Thirty-five days old intact tomato plants were used for all experiments, i.e., wind tunnel and Y-tube bioassays, determination of total nitrogen and volatile compounds containing four to five fully expanded leaves (Supplementary Figure S1).

\section{Insect Rearing}

The whiteflies, B. tabaci MEAM1 (Frohlich et al., 1999), were mass-reared in walk-in insectaries in large screen cages $(60 \mathrm{~cm} \times 60 \mathrm{~cm} \times 60 \mathrm{~cm})$ on eggplant Solanum melongena L. (Solanaceae) cv. 'Zichangqie' which was grown in $15 \mathrm{~cm}$ diameter plastic pots containing 5:1:1 by volume of peat moss, perlite and vermiculite. The insectaries were maintained at $25 \pm 1{ }^{\circ} \mathrm{C}$ with $60 \pm 5 \% \mathrm{RH}$ and a 16:8 h L:D at a light intensity of 1400-1725 lux, which was similar to the experimental environments in which tomato plants were grown.

\section{Wind Tunnel Bioassays}

Response of adult $B$. tabaci toward different levels of nitrogen applied tomato plants was tested in a plexiglass wind tunnel $(200 \mathrm{~cm} \times 70 \mathrm{~cm} \times 70 \mathrm{~cm})$ which was set up in a small controlled environmental room (temperature $25 \pm 1^{\circ} \mathrm{C}$, $\mathrm{RH} 60 \pm 5 \%$ ). A blower pulled the air, and the airflow rate was adjusted at
$22 \mathrm{~cm} \mathrm{~s}^{-1}$. Three $18 \mathrm{~W}$ fluorescent lamps were set up at the take-off point in the flight chamber. The plastic pot except the plant was covered with polythene bags (EasyOne Oven Bags, Reynolds Kitchens, Lake Forest, Illinois, USA) and aluminum foil to minimize plant-growing media produced volatiles before using the plants. In this test, at a time two different nitrogen doses applied intact tomato plants were placed next to each other on the upwind end of the arena maintaining $30 \mathrm{~cm}$ distance to observe that the male or female B. tabaci would fly upwind in the presence of both visual and volatile plant cues. A petri dish containing 100 male or female $B$. tabaci was kept inside the wind tunnel maintaining a short-distance (1-m) from the two plants. Thereafter, $B$. tabaci were released there to make a choice their suitable host. The $B$. tabaci were released at 12:00 h, and $24 \mathrm{~h}$ later, the individuals were carefully counted to investigate their preference between two nitrogen treatments in the presence of both visual and olfactory cues. Numbers of whitefly adults were counted $24 \mathrm{~h}$ later because it took the adults some time to make a choice and settle down in the wind tunnel against wind flow. Before mass releasing of the whiteflies, five individuals were pre-released to ensure that the mass release does not affect the responses of the whiteflies to the odor sources. Each experiment was conducted three times. The wind tunnel was wiped thoroughly with $70 \%$ ethanol and air was pulled through the wind tunnel for at least $2 \mathrm{~h}$ before it was re-used.

\section{Olfactory Choice Test with Y-Tube Olfactometer}

A Y-tube olfactometer was used to evaluate the behavioral response of $B$. tabaci to nitrogen applied tomato plant volatile compounds, following the procedure as previously described by Akol et al. (2003) and Saad et al. (2015) with some modifications. The transparent glass made Y-tube olfactometer consisted of $8 \mathrm{~cm}$ long base with $0.8 \mathrm{~cm}$ internal diameter, two $8 \mathrm{~cm}$ lateral branches at a $60^{\circ}$ angle from each other. The lateral branches were individually connected to two $3 \mathrm{~L}$ glass container with odorless tubes and each glass container contained volatiles releasing one intact tomato plant from each nitrogen treatments. The plant was kept in the glass container for $1 \mathrm{~h}$ before sampling for exiting impure volatiles from the system. Plant containing glass containers were covered with thick paper so that B. tabaci individual cannot receive visual cues from the plants. Charcoal filtered humidified and purified air was provided at $100 \mathrm{ml} \mathrm{min}^{-1}$ to both branches of the Y-tube via odor sources using a vacuum pump (Beijing BCHP Analytical Technology Institute, China) for circulating the volatile organic compounds. The air flow was adjusted and measured by an inline flowmeter (LZB-3WB, Changzhou, Jiangsu, China). Male and female B. tabaci were tested separately. Adult whiteflies were starved for $2 \mathrm{~h}$ and then released within $0.5-1.0 \mathrm{~cm}$ of the base of the Y-tube with a small PCR tube and their responses assessed for $10 \mathrm{~min}$. A B. tabaci adult that walked into one of the lateral branches of the Y-tube at least $5 \mathrm{~cm}$, stayed a minimum of half a minute and did not return was considered as a positive, responsive individual. If an individual did not make a decision within $10 \mathrm{~min}$, they were 
excluded from the results, and considered as non-responsive insect. To eliminate lighting bias, a $20 \mathrm{~W}$ fluorescent light was placed vertically $0.5 \mathrm{~m}$ over the Y-tube olfactometer. The positions of two lateral branches of the Y-tube were inverted $180^{\circ}$ after every five insects tested. Each olfactory test was repeated two times for each combination of stimulus pairs, and each replicate consisted of $25 \mathrm{~B}$. tabaci adults tested individually, i.e., a total of $50 \mathrm{~B}$. tabaci adults for each treatment were assayed. The experiment was carried out between 12.00 and $16.00 \mathrm{~h}$ in a controlled environment maintained at $25 \pm 1^{\circ} \mathrm{C}$ and $60 \pm 5 \%$ relative humidity. To minimize plant-growing media produced volatiles, the pot except the plant was covered with the same polythene bags and aluminum foil as described previously. The experimental Y-tube and all glassware were washed with soap with tap water, then distilled water, and finally sterilized with 70\% ethyl alcohol before oven drying $\left(120^{\circ} \mathrm{C}\right.$ for $\left.3 \mathrm{~h}\right)$ to reduce the contamination risk of previous tested odors.

\section{Determination of Nitrogen from Tomato Plants}

Tomato plants (leaves with stem) were taken separately from each treatment and oven dried at $65^{\circ} \mathrm{C}$ for 4 days. The dried plant samples were ground with a mortar and a pestle, taken in poly bag and preserved it at room temperature before analysis. Total nitrogen from tomato plant tissues was measured using the Kjeldahl method. Exactly $0.1 \mathrm{~g}$ sample was digested with $4 \mathrm{ml}$ of $\mathrm{H}_{2} \mathrm{SO}_{4}$ at $420^{\circ} \mathrm{C}$ for $1 \mathrm{~h}$ along with catalyst of $\mathrm{K}_{2} \mathrm{SO}_{4}$ and $\mathrm{CuSO}_{4}$ at a ratio of 9:1. FOSS 8400 automatic Kjeldahl apparatus (FOSS Analytical AB, Sweden) was used to analyze total nitrogen from tomato plant tissues. Five samples from each treatment were used to measure the quantity of nitrogen.

\section{Volatile Compound Collection from Nitrogen Applied Tomato Plants}

Different levels of nitrogen-treated tomato plants released dynamic headspace volatiles were collected with solid phase micro extraction (SPME) fiber coated with poly dimethyl siloxane-divinyl benzene (PDMS-DVB, $65 \mu \mathrm{m}$ ) purchased from Supelco (Bellefonte, PA, USA). The volatile collection procedure is shown in Figure 1. Previously, many researchers collected VOCs in headspace static using the SPME method by placing a plant in a closed chamber, and this method consequently increased the temperature and relative humidity in the chamber, which could affect the normal physiological process in volatile chemicals emissions (Gouinguenè and Turlings, 2002; Egigu et al., 2014). In our experiment, VOCs were collected using the headspace dynamic SPME method. Here, a continuous airflow went through a 35-days old plant which was confined inside a glass jar $(3 \mathrm{~L})$ that minimized the variation of temperature and humidity inside the glass jar. Again, the same polythene bags and aluminum foil were used to avoid plant-growing media produced volatiles as described previously. On the top of the lid of the glass container was a large hole that closed with a glass made cover containing a bend opening ( $4 \mathrm{~mm}$ in diameter) which was used to insert the SPME fiber. At the bottom of the glass container was another hole for ventilation. A vacuum pump was used for circulating the air which was purified with activated charcoal and thereafter a Tenax TA adsorbent. The flow rate of the air was maintained at $200 \mathrm{ml} \mathrm{min}^{-1}$ with a flow meter. The SPME fiber was conditioned at $250^{\circ} \mathrm{C}$ for $30 \mathrm{~min}$ in a gas chromatograph injection port according to the guideline of the manufacturer. The plant was kept in the glass container for $1 \mathrm{~h}$ before sampling for exiting impure volatiles from the system. The SPME needle

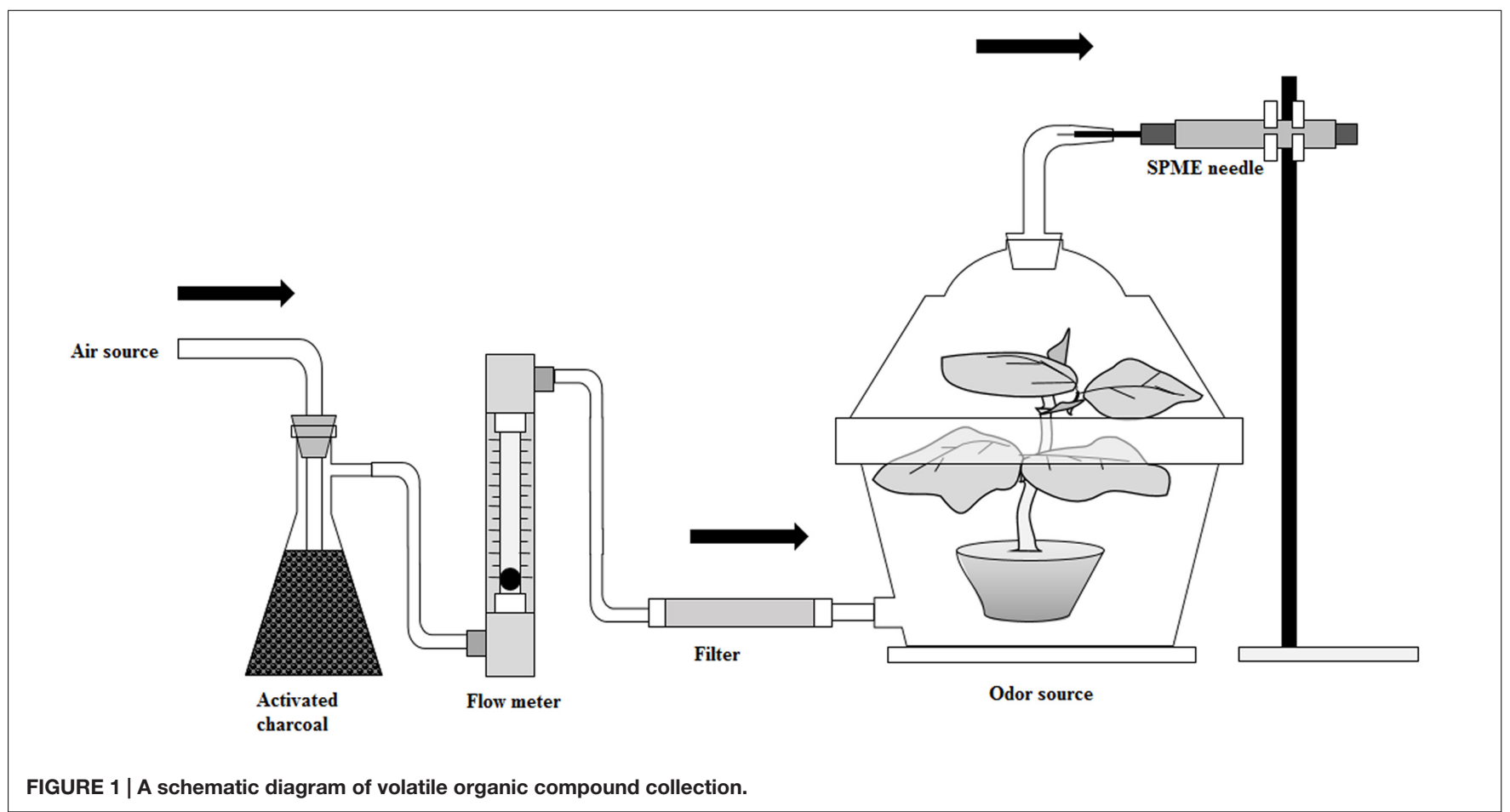


was inserted into the opening of the glass container and extended the fiber to absorb dynamic headspace plant volatiles which escaped through the opening of the glass container for $1 \mathrm{~h}$. After absorption of the volatiles, the SPME needle was directly inserted into a gas chromatograph-mass spectrometer (GC-MS) thermal desorption port as soon as possible, and thereafter the fiber was extended and kept 5 min for desorption of volatile substances.

\section{Analysis of Volatile Compounds}

The system consisted of a GC (TRACE 1310, Thermo Fisher Scientific, Waltham, MA, USA) that was used for the separation of volatile chemicals and an MS (ISQ Single Quadrupole MS, Thermo Fisher Scientific, Waltham, MA, USA) used for their detection, identification, and quantification. The thermally desorbed VOCs were separated in a $30 \mathrm{~m} \times 0.25 \mathrm{~mm} \times 0.25 \mu \mathrm{m}$ film thickness fused silica capillary column (Zebron, ZB-5 MS Ui). Programming splitless injector temperature was maintained at $250^{\circ} \mathrm{C}$ whereas MS transfer line and ion source temperatures were maintained at $280^{\circ} \mathrm{C}$. The purified helium (99.999\%) was used as a carrier gas and the flow rate was maintained at $1.0 \mathrm{ml}$ $\min ^{-1}$ with constant mode. The initial GC oven temperature was set to $40^{\circ} \mathrm{C}$ for $4 \mathrm{~min}$. The oven temperature was increased from 40 to $250^{\circ} \mathrm{C}$ at a rate of $8^{\circ} \mathrm{C} \mathrm{min}^{-1}$ and held for $5 \mathrm{~min}$. The MS was operated in an electron ionization (EI) mode. The ion energy and emission current were maintained at $70 \mathrm{eV}$ and $25 \mu \mathrm{A}$, respectively. The Xcalibur program (Ver. 2.1, Thermo Electron Corporation, USA) was used for data acquisition which was performed in a total ion chromatogram (TIC) with mass range from 33 to 500 amu. The identification of separated compounds was carried out with NIST 2008 (National Institute of Standards and Technology, Washington, DC, USA) database. Kovats retention index (KI) was calculated for each constituent in relation to a mixture of $n$-alkanes standard (Van Den Dool and Kratz, 1963), and $\mathrm{C}_{7}-\mathrm{C}_{40}$ (Sigma-Aldrich, Louis, MO, USA). The data were matched to previously published data (Table 1). The peak area of each component of the volatiles was the relative quantity (Fang et al., 2013).

\section{Statistical Analyses}

IBM SPSS statistics version 19 (Chicago, IL, USA) was used to conduct all statistical analyses. Data produced from Y-tube olfactometer choice bioassays were analyzed by $X^{2}$ test. Wind tunnel bioassay data were analyzed by paired $t$-test. Tomato plant volatiles and nitrogen were analyzed through one-way analysis of variance (ANOVA); means were separated by the Tukey test. Correlation was used to identify a possible relationship between different levels of nitrogen and volatile constituent production of tomato plants. In all cases, means were considered significant at $P<0.05$ level.

\section{RESULTS}

\section{Two-Way Choice Tests Conducted in a Wind Tunnel}

Different levels of nitrogen-treated tomato plants were tested in the wind tunnel to investigate their attractiveness to $B$. tabaci in the presence of both visual and olfactory cues. The results of these dual choice bioassays are presented in Figure 2 for $B$. tabaci females and Figure 3 for $B$. tabaci males. The attractiveness of B. tabaci females was found different in 5, 10, 15, and $20 \mathrm{mM} \mathrm{N}$ treated tomato plants. The results revealed that significantly more B. tabaci females were found in $15 \mathrm{mM} \mathrm{N}(t=7.317, P<0.05$; Figure 2B) and $20 \mathrm{mM} \mathrm{N}(t=5.034, P<0.05$; Figure 2C) than in $5 \mathrm{mM} \mathrm{N}$ treated tomato plants. When given an option to choose $10 \mathrm{mM}$ versus $15 \mathrm{mMN}$ treated plants, $B$. tabaci females preferred $15 \mathrm{mMN}$ to $10 \mathrm{mMN}$ treated plant $(t=4.508, P<0.05$;

TABLE 1 | Molecular weight, mass peak (m/z), retention time (RT), calculated Kovats indicies (CKI) and tabulated Kovats retention indices (TKI) of the volatile compounds identified from intact tomato plants after four nitrogen treatments (see Figure 6 for relative amounts of volatile organic compounds indicated by peak areas found from different levels of nitrogen-treated tomato plants).

\begin{tabular}{|c|c|c|c|c|c|c|c|c|}
\hline Peak no & Compounds & Chemical class & Molecular weight & Mass peak $(\mathrm{m} / \mathrm{z})$ & RT (min) & CKI & TKI & Reference \\
\hline 1 & Heptanal & Alkyl aldehyde & 114 & $70,44,41,55$ & 6.95 & 903 & 901 & Babushok and Zenkevich, 2008 \\
\hline 2 & $\alpha$-Pinene & Monoterpene & 136 & $93,91,92,77$ & 7.65 & 932 & 932 & Adams, 2009 \\
\hline 3 & $\beta$-Pinene & Monoterpene & 136 & $93,41,69,91$ & 8.58 & 970 & 973 & Franco et al., 2011 \\
\hline 4 & Myrcene & Monoterpene & 136 & $41,93,69,53$ & 9.14 & 993 & 990 & Adams, 2009 \\
\hline 5 & $(+)$-4-carene & Monoterpene & 136 & $93,121,136,91$ & 9.30 & 1000 & 1001 & Le Quere and Latrasse, 1990 \\
\hline 6 & $\alpha$-Terpinene & Monoterpene & 136 & $93,121,91,136$ & 9.69 & 1018 & 1019 & Franco et al., 2011 \\
\hline 7 & p-Cymene & Monoterpene & 134 & $119,134,91,120$ & 9.86 & 1025 & 1023 & Franco et al., 2011 \\
\hline 8 & $\beta$-Phellandrene & Monoterpene & 136 & $93,77,91,136$ & 9.94 & 1029 & 1029 & Franco et al., 2011 \\
\hline 9 & Nonanal & Alkyl aldehyde & 142 & $57,41,43,56$ & 11.63 & 1108 & 1108 & Engel et al., 2002 \\
\hline 10 & $\delta$-Elemene & Sesquiterpene & 204 & $121,93,41,107$ & 15.96 & 1343 & 1338 & Adams, 2009 \\
\hline 11 & $\alpha$-Copaene & Sesquiterpene & 204 & $161,119,105,93$ & 16.61 & 1382 & 1376 & Franco et al., 2011 \\
\hline 12 & Longifolene & Sesquiterpene & 204 & $161,94,91,93$ & 17.12 & 1413 & 1416 & Hognadottir and Rouseff, 2003 \\
\hline 13 & $\alpha$-Cedrene & Sesquiterpene & 204 & $119,93,105,204$ & 17.23 & 1420 & 1419 & Da Cruz et al., 2014 \\
\hline 14 & $\beta$-Caryophyllene & Sesquiterpene & 204 & $93,133,91,41$ & 17.34 & 1427 & 1425 & Da Cruz et al., 2014 \\
\hline 15 & $\alpha$-Humulene & Sesquiterpene & 204 & $93,80,41,121$ & 17.88 & 1462 & 1460 & Da Cruz et al., 2014 \\
\hline 16 & Farnesan & Alkane & 212 & $57,71,43,41$ & 20.01 & 1604 & - & - \\
\hline
\end{tabular}



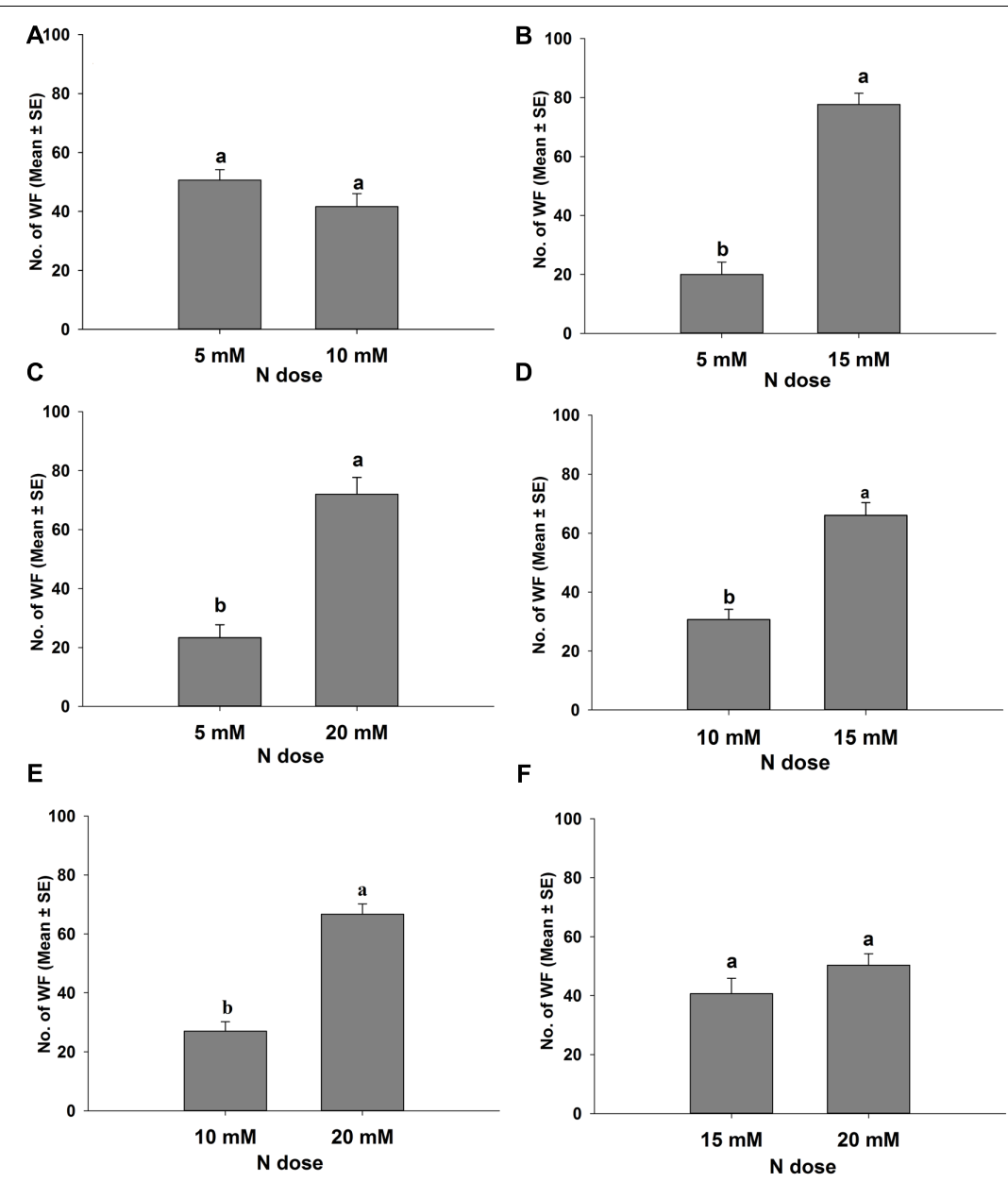

FIGURE 2 | Response of Bemisia tabaci females in different levels of nitrogen applied tomato plants in a wind tunnel experiment. Different letters are denoted significantly different at $P<0.05$, and the same letters are denoted not-significant at $P=0.05$ (Paired $t$-test). (A) 5 and $10 \mathrm{mM} \mathrm{N}$; (B) 5 and $15 \mathrm{mM} \mathrm{N}$; (C) 5 and $20 \mathrm{mM} \mathrm{N}$; (D) 10 and $15 \mathrm{mM} \mathrm{N}$; (E) 10 and $20 \mathrm{mM} \mathrm{N}$; (F) 15 and $20 \mathrm{mM} \mathrm{N}$ treated tomato plants.

Figure 2D). When $10 \mathrm{mM} \mathrm{N}$ and $20 \mathrm{mM} \mathrm{N}$ were offered, B. tabaci females preferred $20 \mathrm{mM} \mathrm{N}$ to $10 \mathrm{mM} \mathrm{N}$ treated plant $(t=6.263$, $P<0.05$; Figure 2E). However, $B$. tabaci females did not show significant preference between $5 \mathrm{mM} \mathrm{N}$ and $10 \mathrm{mM} \mathrm{N}(t=1.199$, $P=0.353$; Figure 2A) and between $15 \mathrm{mM} \mathrm{N}$ and $20 \mathrm{mM} \mathrm{N}$ treated tomato plants ( $t=1.609, P=0.249$; Figure 2F).

The data from the wind tunnel dual choice test showed that adult $B$. tabaci males did not have significant preference between $5 \mathrm{mM} \mathrm{N}$ and $10 \mathrm{mM} \mathrm{N}(t=0.122, P=0.914$; Figure 3A), between $5 \mathrm{mM} \mathrm{N}$ and $15 \mathrm{mM} \mathrm{N}(t=2.592, P=0.122$; Figure 3B), between $5 \mathrm{mM} \mathrm{N}$ and $20 \mathrm{mM} \mathrm{N}(t=0.610, P=0.604$; Figure 3C), between $10 \mathrm{mM} \mathrm{N}$ and $15 \mathrm{mM} \mathrm{N}(t=1.131, P=0.375$; Figure 3D), between $10 \mathrm{mM} \mathrm{N}$ and $20 \mathrm{mM} \mathrm{N}(t=1.113, P=0.382$; Figure 3E), and between $15 \mathrm{mM} \mathrm{N}$ and $20 \mathrm{mM} \mathrm{N}(t=0.355$, $P=0.757$; Figure 3 F) treated tomato plants.

\section{Olfactory Bioassay with Y-Tube Olfactometer}

The preferences of $B$. tabaci were assayed in the Y-tube olfactometer toward volatile blends released from different levels of nitrogen-treated tomato plants, and the results are shown in Figure 4A for B. tabaci females and Figure $4 \mathrm{~B}$ for $B$. tabaci males. Adult $B$. tabaci females showed significant preference among the VOCs of the plants treated with various levels of nitrogen including $5,10,15$, and $20 \mathrm{mM} \mathrm{N}$. Significantly more $B$. tabaci females were attracted to $15 \mathrm{mM} \mathrm{N}\left(\chi^{2}=8.333 ; P<0.01\right)$ than $5 \mathrm{mM} \mathrm{N}$ when $5 \mathrm{mM} \mathrm{N}$ and $15 \mathrm{mM} \mathrm{N}$ were offered, and to $20 \mathrm{mM} \mathrm{N}\left(\chi^{2}=5.333 ; P<0.05\right)$ when $5 \mathrm{mM} \mathrm{N}$ and $20 \mathrm{mM} N$ were offered. Similarly, B. tabaci females preferred $15 \mathrm{mM} \mathrm{N}$ when $10 \mathrm{mM} \mathrm{N}$ and $15 \mathrm{mM} \mathrm{N}$ treated tomato plants were offered $\left(\chi^{2}=5.000 ; P<0.05\right)$, and preferred $20 \mathrm{mM}$ $\mathrm{N}\left(\chi^{2}=5.488 ; P<0.05\right)$ when $10 \mathrm{mM} \mathrm{N}$ and $20 \mathrm{mM} \mathrm{N}$ treated tomato plants were offered. However, B. tabaci females did not show significant preference between $5 \mathrm{mM} \mathrm{N}$ and $10 \mathrm{mM} \mathrm{N}\left(\chi^{2}=0.556 ; P=0.456\right)$, and between $15 \mathrm{mM} \mathrm{N}$ and $20 \mathrm{mM} \mathrm{N}\left(\chi^{2}=1.043 ; P=0.307\right)$ treated tomato plants (Figure 4A).

However, in the choice tests, $B$. tabaci male adults did not show any significant preference among the VOCs from the plants treated with different levels of nitrogen $(5 \mathrm{mM} \mathrm{N}$ and $10 \mathrm{mM}$ 

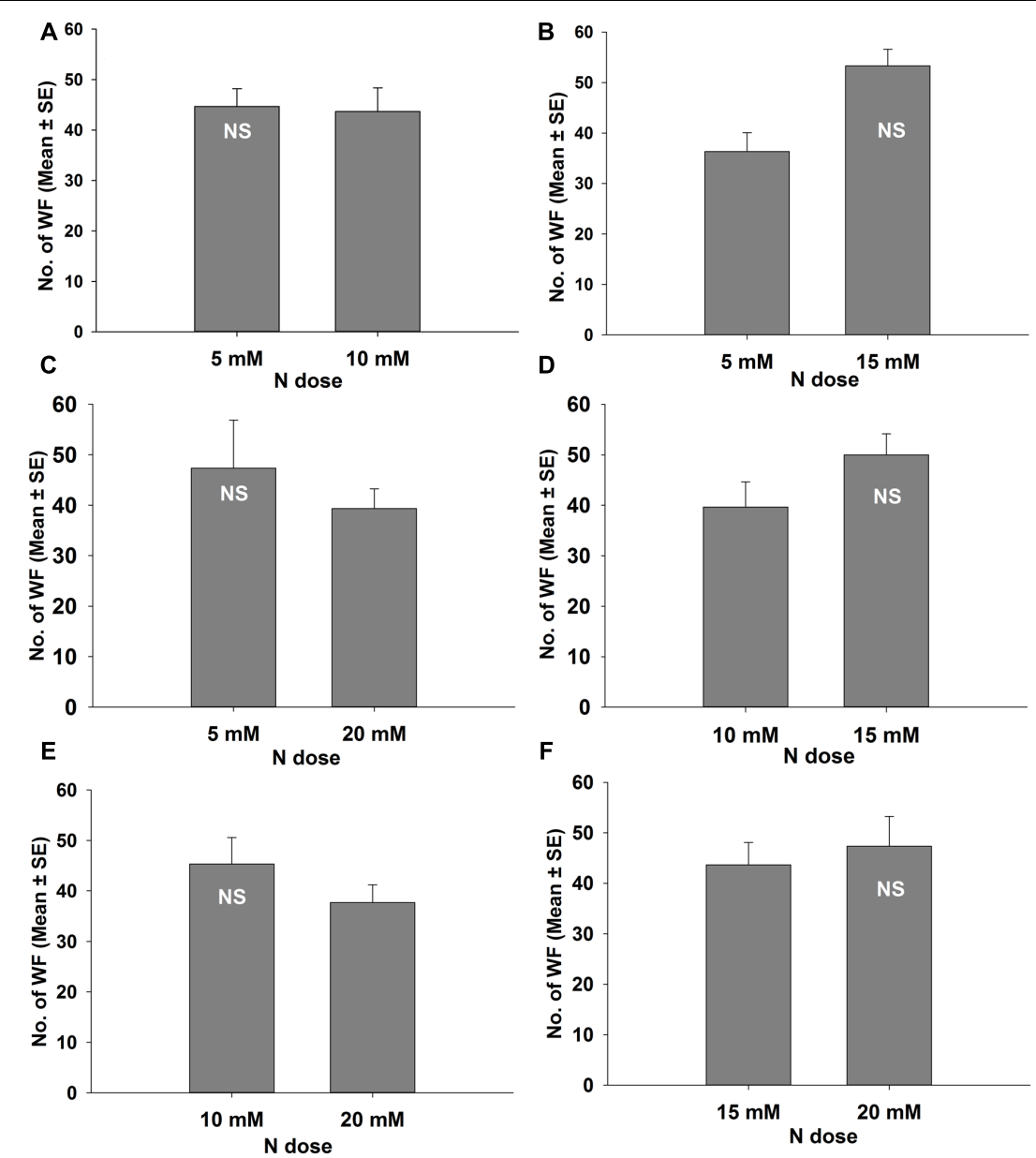

FIGURE 3 | Response of $\boldsymbol{B}$. tabaci males in different levels of nitrogen applied tomato plants in a wind tunnel experiment. NS, denoted not significant at $P=0.05$ (Paired t-test). (A) 5 and $10 \mathrm{mM} \mathrm{N}$; (B) 5 and $15 \mathrm{mM} \mathrm{N}$; (C) 5 and $20 \mathrm{mM} \mathrm{N}$; (D) 10 and $15 \mathrm{mM} \mathrm{N}$; (E) 10 and $20 \mathrm{mM} \mathrm{N}$; (F) 15 and $20 \mathrm{mM} \mathrm{N}$ treated tomato plants.

$\mathrm{N}: \chi^{2}=1.333 ; P=0.248 ; 5 \mathrm{mM} \mathrm{N}$ and $15 \mathrm{mM} \mathrm{N}: \chi^{2}=0.364$; $P=0.546 ; 5 \mathrm{mM} \mathrm{N}$ and $20 \mathrm{mM} \mathrm{N}: \chi^{2}=1.140 ; P=0.286 ; 10 \mathrm{mM}$ $\mathrm{N}$ and $15 \mathrm{mM} \mathrm{N}: \chi^{2}=0.000 ; P=1.000 ; 10 \mathrm{mM} \mathrm{N}$ and $20 \mathrm{mM} \mathrm{N}$ : $\chi^{2}=2.689 ; P=0.101$; and $15 \mathrm{mM} \mathrm{N}$ and $20 \mathrm{mM} \mathrm{N}: \chi^{2}=0.184$; $P=0.668)$ (Figure 4B).

\section{Amounts of Nitrogen in Tomato Plants}

The results of total nitrogen in different levels of nitrogen-treated tomato plants are shown in Figure 5. Significant variation of total nitrogen in tomato plants (leaves with stem) were found due to different levels of nitrogen application. Tomato plants grown in $15 \mathrm{mM}\left(\mathrm{T}_{3}\right)$ and $20 \mathrm{mM}\left(\mathrm{T}_{4}\right)$ nitrogen levels had significantly higher percentage of total nitrogen than the plants grown in $5 \mathrm{mM}\left(\mathrm{T}_{1}\right)$ and $10 \mathrm{mM}\left(\mathrm{T}_{2}\right)$ nitrogen $\left(F_{3,16}=12.163\right.$, $P<0.001)$. There was no significantly difference of percentages of total nitrogen in $T_{1}$ and $T_{2}$ treatments. Similarly, no significant difference of percentages of total nitrogen was observed between $\mathrm{T}_{3}$ and $\mathrm{T}_{4}$ treatments (Figure 5). However, different levels of nitrogen affected plant weight (Supplementary Figure S2).

\section{Volatile Organic Compounds Identified from Intact Tomato Plants after Application of Different Levels of Nitrogen, Quantity of Volatile Constituents and Correlation between Nitrogen Levels}

Effects of nitrogen on tomato plant VOCs are shown in Figures $6 \mathrm{~A}-\mathrm{P}$, and GC-MS chromatograms of volatiles are presented in Figures 7A-D. Sixteen VOCs were identified from the tomato plants with nitrogen fertilization treatments. Besides plant emitted VOCs, some compounds are generally related with the analytical system such as phthalates or siloxanes, as well as compounds related with earth's atmosphere such as benzene and toluene (Warneke et al., 2001; Jansen et al., 2008) were not included in the list. The quantities of eight VOCs emitted from tomato plants, including heptanal $\left(F_{3,12}=2.461, P=0.113\right.$; Figure 6A), $\alpha$-pinene $\left(F_{3,12}=2.367\right.$, $P=0.122$; Figure 6B), myrcene $\left(F_{3,12}=1.993, P=0.169\right.$; Figure 6D), nonanal $\left(F_{3,12}=0.220, P=0.881\right.$; Figure 6I), 


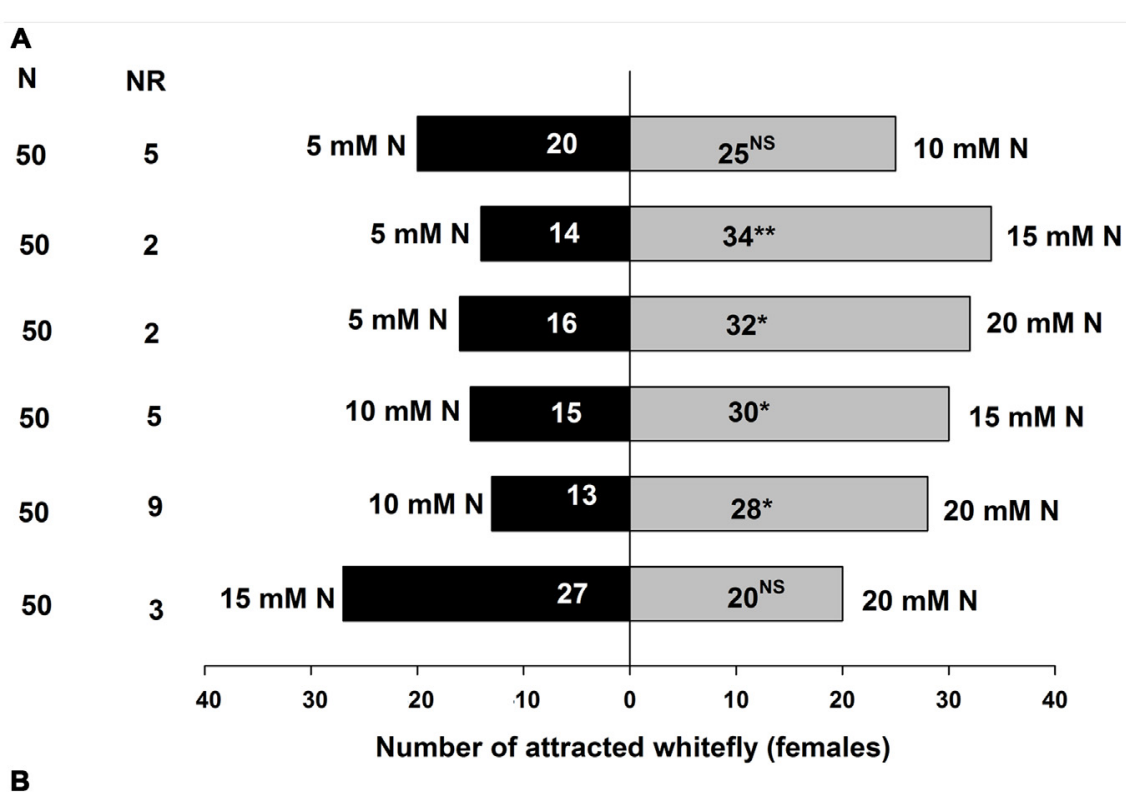

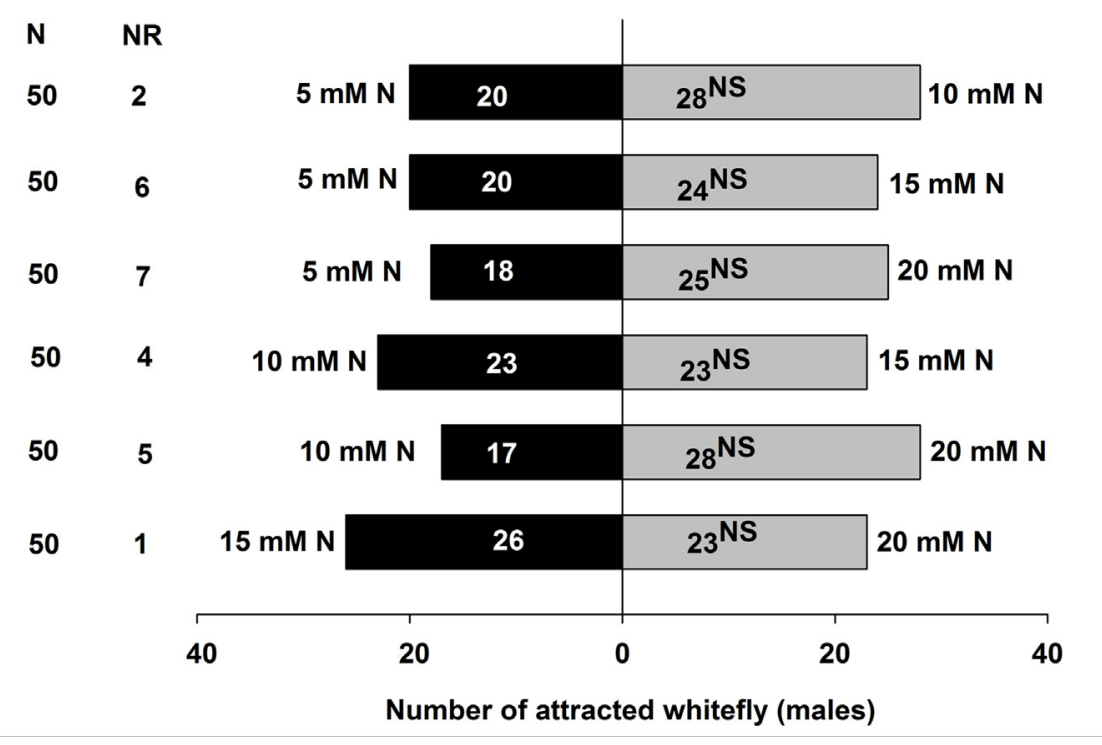

FIGURE 4 | Olfactory responses of $\boldsymbol{B}$. tabaci females (A) and males (B) in Y-tube olfactometer assay given a choice between volatile compounds from tomato plants treated with different doses of nitrogen. N, numbers of $B$. tabaci females and males tested. NR, Number of non-responsive insects. NS, Not significantly different at $P=0.05$. *, Significantly different at $P<0.05$. ${ }^{*}$, Significantly different at $P<0.01\left(X^{2}\right.$ test).

S-elemene $\left(F_{3,12}=2.007, P=0.167\right.$; Figure 6J), longifolene $\left(F_{3,12}=0.177, P=0.910\right.$; Figure 6L), $\alpha$-cedrene $\left(F_{3,12}=0.733\right.$, $P=0.552$; Figure 6M), and farnesan $\left(F_{3,12}=0.178, P=0.909\right.$; Figure 6P), were not significantly varied with increasing nitrogen treatments. The quantities in the remaining eight identified volatiles differed significantly among the $\mathrm{N}$ levels applied, including $\beta$-pinene $\left(F_{3,12}=8.863, P<0.01\right.$; Figure $\left.6 \mathrm{C}\right)$, $(+)$-4-carene $\left(F_{3,12}=7.853, P<0.01\right.$; Figure $\left.6 \mathrm{E}\right), \alpha$-terpinene $\left(F_{3,12}=5.290, P<0.05\right.$; Figure $\left.6 \mathrm{~F}\right), \mathrm{p}$-cymene $\left(F_{3,12}=5.875\right.$, $P<0.05 ;$ Figure 6G), $\beta$-phellandrene $\left(F_{3,12}=14.110\right.$, $P<0.001$; Figure 6H), $\alpha$-copaene $\left(F_{3,12}=16.683, P<0.001\right.$;
Figure 6K), $\beta$-caryophyllene $\left(F_{3,12}=29.783, P<0.001\right.$; Figure $6 \mathrm{~N})$, and $\alpha$-humulene $\left(F_{3,12}=9.029, P<0.01\right.$; Figure 60). Of the eight significantly varied VOCs including $\beta$-pinene, $(+)$-4-carene, $\alpha$-terpinene, $\mathrm{p}$-cymene, $\beta$-phellandrene, $\alpha$-copaene, $\beta$-caryophyllene, and $\alpha$-humulene, no significant differences were found between $5 \mathrm{mM}\left(\mathrm{T}_{1}\right)$ and $10 \mathrm{mM}\left(\mathrm{T}_{2}\right)$ nitrogen-treated plant volatiles except for $\beta$-pinene, $\mathrm{p}$-cymene, and $\alpha$-humulene. The tomato plants at $15 \mathrm{mM}\left(\mathrm{T}_{3}\right)$ and $20 \mathrm{mM}\left(\mathrm{T}_{4}\right)$ nitrogen produced significantly lower levels of $\beta$-pinene, $(+)$-4-carene, $\alpha$-terpinene, $\mathrm{p}$-cymene, $\beta$-phellandrene, $\alpha$-copaene, $\beta$-caryophyllene, and $\alpha$-humulene as compared with 


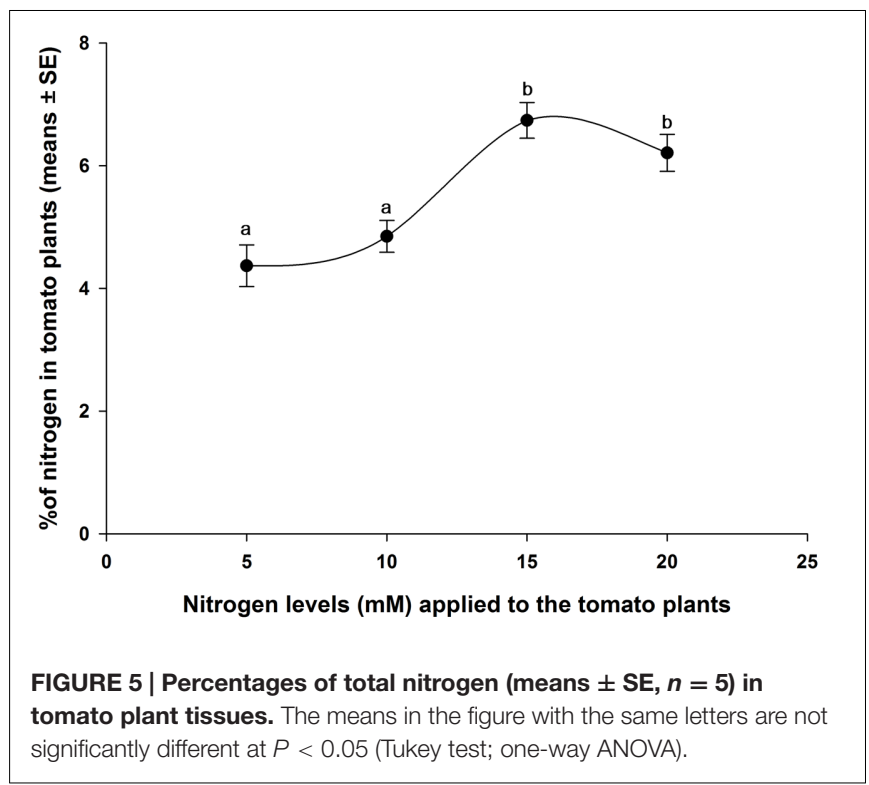

the tomato plants grown at the $5 \mathrm{mM}\left(\mathrm{T}_{1}\right)$ and $10 \mathrm{mM}$ $\left(\mathrm{T}_{2}\right)$ nitrogen. Of the eight significantly varied VOCs, no significant differences were observed between $15 \mathrm{mM}\left(\mathrm{T}_{3}\right)$ and $20 \mathrm{mM}\left(\mathrm{T}_{4}\right)$ nitrogen-treated plant volatiles except for $\alpha$-terpinene and $\alpha$-humulene. The amounts of significantly varied eight VOCs identified are well and negatively correlated with the $\mathrm{N}$ levels in the tomato plants, the higher the $\mathrm{N}$ levels, the lower of the VOCs identified $(r=-0.883$ to $-0.967)$.

\section{DISCUSSION}

In our study, the tomato plants treated with below normal and normal nitrogen levels of nitrogen $\left(\mathrm{T}_{1}\right.$ and $\left.\mathrm{T}_{2}\right)$ had similar plant nitrogen contents. Similarly, the tomato plants treated with higher nitrogen levels $\left(\mathrm{T}_{3}\right.$ and $\left.\mathrm{T}_{4}\right)$ showed similar plant nitrogen contents (Figure 5). Han et al. (2014) reported that optimal nitrogen-treated tomato plants showed statistically similar leaf nitrogen content to those treated with high nitrogen, but the amount of tomato leaf nitrogen was statistically higher than the plants treated with low levels of nitrogen input. However, our results demonstrated that the nitrogen induced VOCs emitted from tomato plants influenced the behavioral responses of B. tabaci female to host plants. For instance, in the wind tunnel bioassay, B. tabaci females preferred higher levels of nitrogentreated tomato plants (Figure 2). The Y-tube olfactometer tests were also provided strong evidence that $B$. tabaci females chose the VOCs from $\mathrm{T}_{3}$ and $\mathrm{T}_{4}$ plants without visual or physical contact with the plants (Figure 4A). In the free-choice experiment, the whiteflies could make a decision to choose their host plant with different morphological characteristics, volatile constituents of the plants, or both. However, in the olfactometer experiments, the whiteflies chose the plants only based on the VOCs from the plant, not the morphological characters. Addesso and McAuslane (2009) reported that without volatile compounds, the pepper weevil (Anthonomus eugenii) adults were more inclined to move downwind or remain stationary than to move upwind in the wind tunnel. Therefore, volatile compounds play a critical role to choose the host plant. In our study, the whiteflies showed similar preferences to the VOC from the plants treated with different amounts of nitrogen in both the wind tunnel and the olfactometer experiments. These results are consistent with the findings of Saad et al. (2015) who found that the host plant preference of $B$. tabaci was similar in the free-choice and olfactometer experiments.

The wind tunnel and Y-tube olfactometer bioassays revealed that the females and males of $B$. tabaci had different responses to the VOCs emitted from the plants treated with different amounts of nitrogen. For instance, the male adults of $B$. tabaci did not show any preference to the VOCs emitted from the plants treated with different amounts of nitrogen (Figures 3, 4B). It is generally believed that females play a greater role in finding plants for oviposition for offspring development than males (Zu Dohna, 2006). Moreover, this host finding behavioral difference between the sexes supported the general pattern where many female insects are more attracted by host plant odors than males (Raguso et al., 1996; Zhang et al., 1999; Das et al., 2007; Szendrei and Rodriguèz-Saona, 2010). Saad et al. (2013) and Zheng et al. (2013) reported that B. tabaci and Aleurodicus dispersus females significantly preferred chili plant odors and hexanol isomers, respectively, in an olfactometer assay whereas the males did not show significant responses. Sex-specific olfactory responses and host selection of $B$. tabaci based on volatile compounds are comparatively poorly studied. It is possible that volatile chemicals emitted by host plants are assumed to mainly affect females (Finch, 1980), whereas pheromones stimulates higher responses from male insects than from female insects (Li and Maschwitz, 1985). Therefore, further studies on the differences between females and males of $B$. tabaci are needed.

The results of our wind tunnel and olfactometer experiments showed that higher amounts of nitrogen receiving plants, for example $\mathrm{T}_{3}$ and $\mathrm{T}_{4}$, were highly preferred by $B$. tabaci females compare to $\mathrm{T}_{1}$ and $\mathrm{T}_{2}$ nitrogen-treated plants, indicating that the behavioral response of $B$. tabaci females could be attributed quantitative differences of nitrogen induced volatile compounds released by the plants. In the volatile analysis test, we found that highly attractive plants emitted significantly less amount of monoterpenes ( $\beta$-pinene, $(+)$-4-carene, $\alpha$-terpinene, $\beta$-phellandrene, and p-cymene) and sesquiterpenes ( $\alpha$-copaene, $\alpha$-humulene, and $\beta$-caryophyllene) from the intact tomato plants. This result indicated that production of monoterpenes and sesquiterpenes, generally decreased with the increase of nitrogen levels in tomato plants (Figures 5, 6), and these terpene volatiles could influence the behavioral response of $B$. tabaci. This result is in agreement with those reported by Tuomi et al. (1994); Lee et al. (2005), and Chen et al. (2008), who found that plants grown at a high level of fertilizer had a lower terpene concentration than the plants grown in a low level of fertilizer. Similarly, Fretz (1976) reported that a low level of terpene was found in Juniperus horizontalis after additional nitrogen fertilizer 


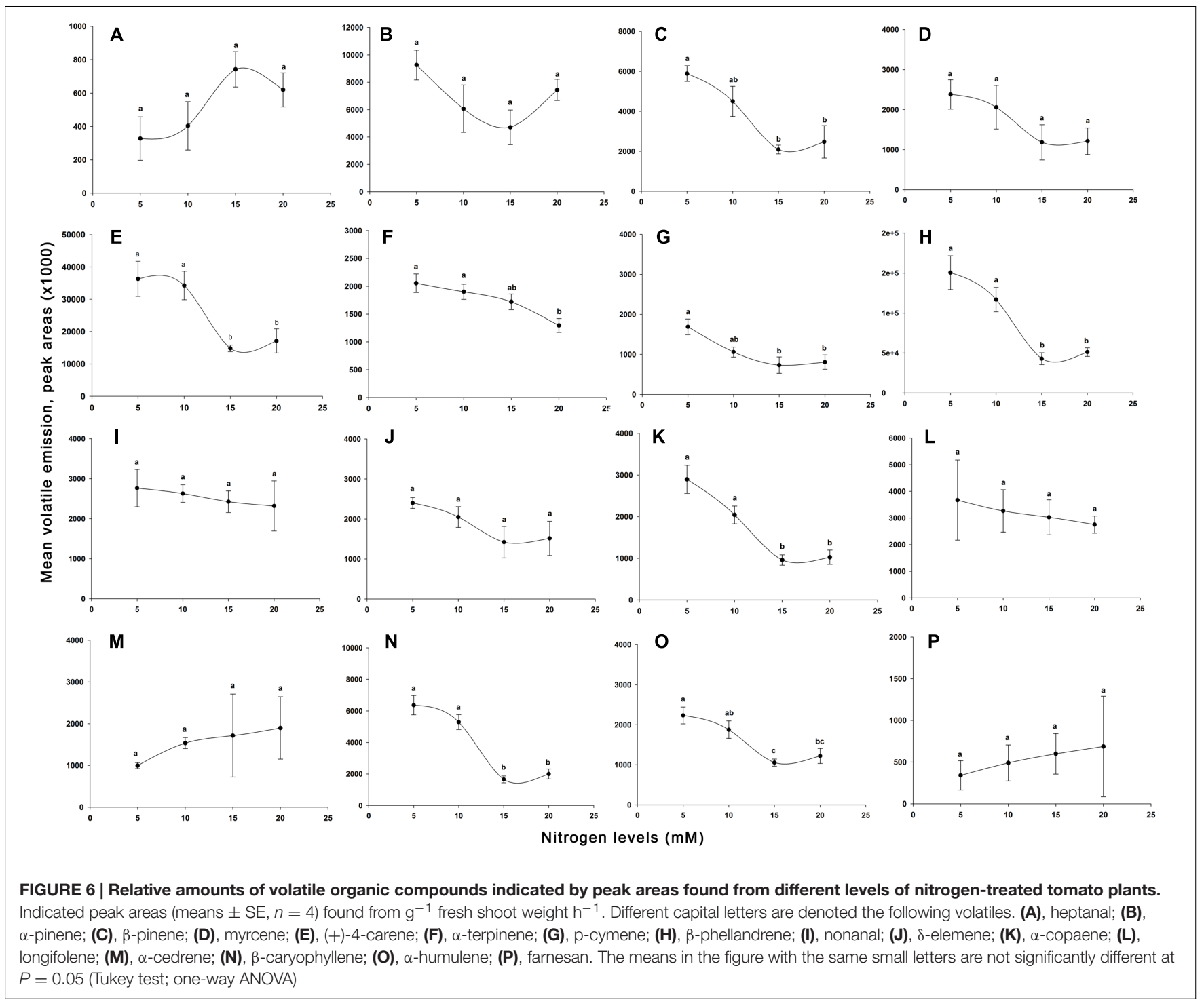

application. It has been found that host plant resistance of $B$. tabaci is related to the optimal nutrient (nitrogen) content of the plants. Reddy and Rao (1989) and Bentz et al. (1995b) reported that nutrient levels (nitrogen) supplied to a plant can increase its nutrient quality, such as, increase of leaf nitrogen content could interfere the natural resistance mechanism of the host plant to insects. Nitrogen may influence nutritional values and semiochemicals of plants and also behavioral characteristics of herbivores. For instance, Jauset et al. (1995) and Zaini et al. (2013) showed that B. tabaci populations were higher when crops were provided with higher levels of nutrients than low levels of nutrients. Our results also showed that $B$. tabaci female preferred the plants with high levels of nitrogen. Therefore, we think that high levels of nitrogen-treated tomato plants exhibited different plant defense mechanism that become more attractive to $B$. tabaci.

The amount of plant VOCs released by individual plants can vary with abiotic factors that impact plant's physiology.
These variations may induce different defense mechanisms of the plants to herbivores, and further affect the infestation performance and behavior of insect pests (Gonzales et al., 2002). In our study, the tomato plant treated with normal and below normal levels of nitrogen emitted high amounts of volatile monoterpenes and sesquiterpenes compared to the plants treated high levels of nitrogen. Monoterpenes and sesquiterpenes increased with the decrease of nitrogen level in tomato plants are consistent with the carbon-nutrient balance hypothesis where predicted secondary metabolites production will be affected in case of lack of any nutrients (Gershenzon and Croteau, 1991). Growth rate of the plant will be reduced due to low nutrient availability but carbohydrate accumulation continues by constant photosynthesis due to carbon availability. Subsequently, accumulation of carbohydrate will lead to synthesis of constitutive secondary compounds like terpenoids (Herms and Mattson, 1992; Gershenzon, 1994). Therefore, we think that $T_{1}$ and $T_{2}$ nitrogen-treated tomato 


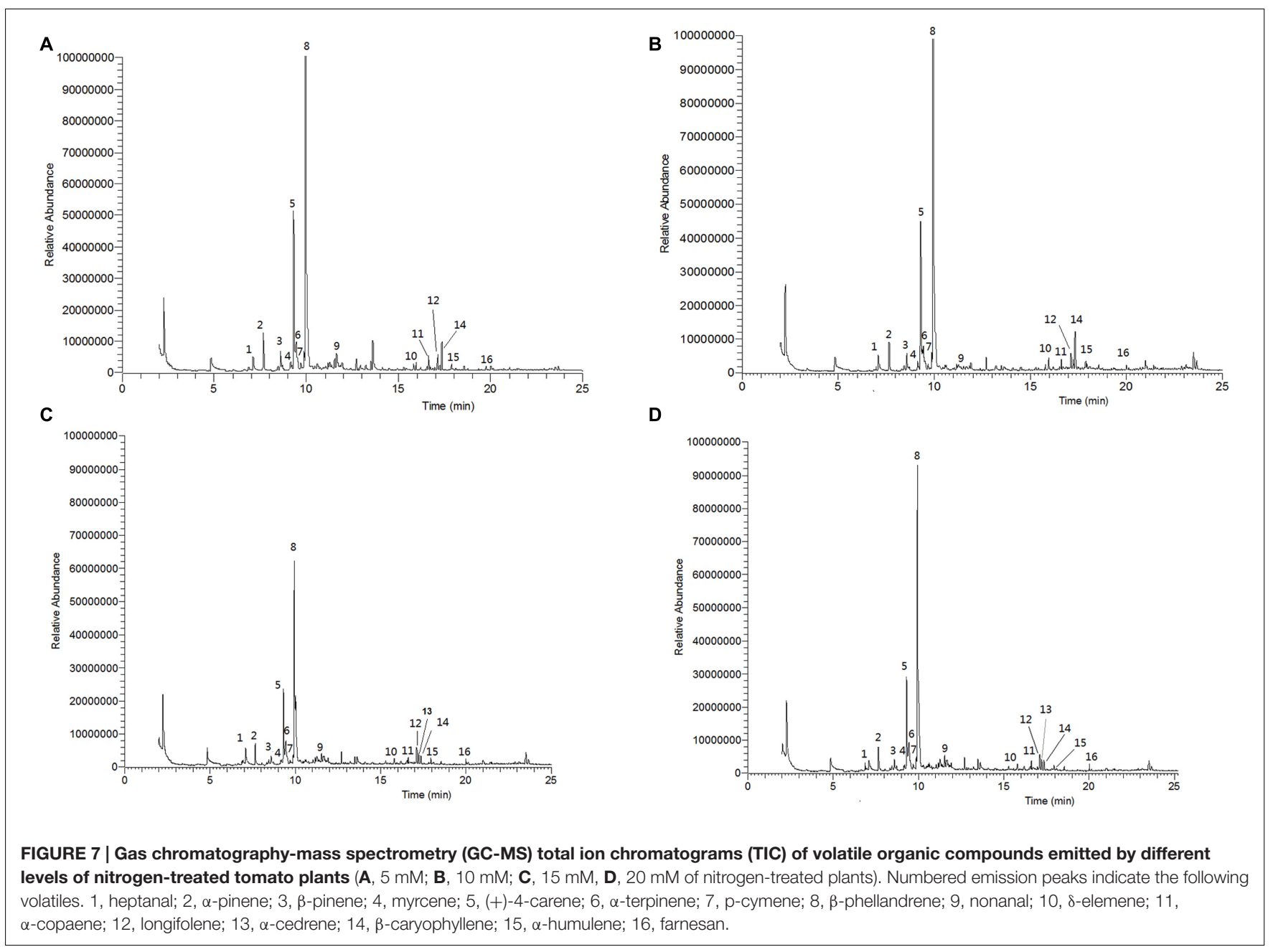

plants produced high amount of insect repelling terpenes, especially, monoterpenes and sesquiterpenes than $\mathrm{T}_{3}$ and $\mathrm{T}_{4}$ nitrogen-treated tomato plants, which is the possibly reason to move a higher number of $B$. tabaci females to $\mathrm{T}_{3}$ and $\mathrm{T}_{4}$ nitrogen-treated tomato plants in both wind tunnel and olfactometer experiments. These terpene volatiles released from plants in low amount are often reduced in defense against herbivores (Bleeker et al., 2009; Fang et al., 2013). A number of monoterpenes and sesquiterpenes have been reported to display repellent property to $B$. tabaci. For example, virus infected tomato plant was significantly susceptible to $B$. tabaci and that plant had a significant lower concentration of the volatiles $\alpha$-pinene, limonene, 4-carene, thymine, $\beta$-phellandrene, caryophyllene, $\alpha$-cedrene, $\beta$-cedrene, and $\alpha$-humulene than the healthy plant (Fang et al., 2013; Luan et al., 2013). Similarly, significantly less amount of monoterpenes (e.g., p-cymene, 1, 8-cineole) and sesquiterpenes (e.g., $\alpha$-copaene, $\beta$-cedrene) emitting healthy plants were more preferred by B. tabaci females than infested plants (Saad et al., 2015). Our results also showed that the concentration of certain terpenes decreased with the increase of nitrogen levels in tomato plants that was significantly attractive to
B. tabaci as shown in the wind tunnel and olfactometer experiments. Zhang et al. (2004) and Yang et al. (2010) conducted a similar olfactory bioassay of $B$. tabaci with a vertical olfactometer and showed that ginger oil extract repelled adult $B$. tabaci. A mixture of volatile constituents, including monoterpenes ( $\mathrm{p}$-cymene, $\alpha$-terpenene, $\beta$-phellandrene, 1,8 cineole, camphene), sesquiterpenes, alcohols, and aldehydes, were associated to the repellent properties of an essential oil (Owolabi et al., 2007; Ukeh et al., 2009; Sa-Nguanpuag et al., 2011; Nampoothiri et al., 2012). Similarly, Simmons and Gurr (2005) and Bleeker et al. (2009) reported that B. tabaci prefer cultivated tomato plants to wild tomato plants, and their work showed that wild tomato plants released higher levels of terpenes, such as p-cymene, $\alpha$-terpinene, $\gamma$-terpinene and phellandrene, which act as a repellent to $B$. tabaci. Besides monoterpenes, the antennae of the whitefly are also able to detect certain sesquiterpenes, such as zinziberene and curcumene even in low concentrations. Olson et al. (2009) reported that Spodoptera exigua larvae preferred a higher level of nitrogen receiving induced cotton plants during their growth to recommended level of nitrogen-treated plant, because of lower amounts of terpene volatiles (e.g., ocimene, linalool, indole) emitted 
from the higher level of nitrogen receiving cotton plants in compare to recommended level of nitrogen receiving plant. These results support the conclusion that nitrogen plays a role in the release of terpenes from tomato plants, which affect host preference of $B$. tabaci.

This experiment provide a valuable message that high levels of nitrogen hampers the defenses of tomato plant against B. tabaci by decreasing the quantity of different volatile organic compounds, including $\beta$-pinene, $(+)$-4-carene, $\alpha$-terpinene, p-cymene, $\beta$-phellandrene, $\alpha$-copaene, $\beta$-caryophyllene, and $\alpha$-humulene. Further study is needed to evaluate each of these volatiles for its effect on the behavior of $B$. tabaci to find out which has the most adverse effect on $B$. tabaci as a repellent or an attractant. This finding can be used in future to identify B. tabaci repellents and attractants that could be used as tools of IPM of B. tabaci and other whitefly pests.

\section{AUTHOR CONTRIBUTIONS}

Conceived and designed the experiments: MI, AH, T-XL. Performed the experiments: MI, AH, YZ, and Z-FZ. Analyzed the data: MI, AH, and YZ. Contributed reagents/materials/analysis tools: $\mathrm{MI}, \mathrm{AH}, \mathrm{YZ}$, and Z-FZ. Wrote the paper: $\mathrm{MI}, \mathrm{AH}$, and T-XL.

\section{REFERENCES}

Adams, R. P. (2009). Identification of Essential Oil Components by Gas Chromatography/Mass Spectrometry. Carol Stream, IL: Allured Books.

Addesso, K. A., and McAuslane, H. J. (2009). Pepper weevils attraction to volatiles from host and nonhost plants. Chem. Ecol. 38, 216-224. doi: 10.1603/022.038. 0127

Akol, A. M., Njagi, P. G. N., Sithanantham, S., and Muke, J. M. (2003). Effects of two neem insecticide formulations on the attractiveness, acceptability and suitability of diamondback moth larvae to the parasitoid, Diadegma mollipla (Holmgren) (Hym., Ichneumonidae). J. Appl. Entomol. 127, 325-331. doi: 10.1046/j.14390418.2003.00771.x

Babushok, V. I., and Zenkevich, I. G. (2008). Retention indices for most frequently reported essential oil compounds in GC. Chromatographia 69, 257-269. doi: 10.1365/s10337-008-0872-3

Bari, M. N., and Sarder, M. A. (1998). Control strategy of aphid with predator, Menochilus sexmaculatus (F.) and insecticides. Bangladesh J. Entomol. 8, 21-29.

Bentz, J. A., Reeves, J. I. I. I., Barbosa, P., and Francis, B. (1995a). Within-plant variation in nitrogen and sugar content of poinsettia and its effects on the oviposition pattern, survival, and development to Bemisia argentifolii. Environ. Entomol. 24, 271-277.

Bentz, J. A., Reeves, J. I. I. I., Barbosa, P., and Francis, B. (1995b). Nitrogen fertilizer effect on selection, acceptance and suitability of Euphorbia pulcherrima as a host plant to Bemisia tabaci. Environ. Entomol. 24, 40-45. doi: 10.1093/ee/24.1.40

Berenbaum, M. R. (1995). The chemistry of defense: theory and practice (1995). Proc. Natl. Acad. Sci. U.S.A. 92, 2-8. doi: 10.1073/pnas.92.1.2

Bernays, E. A. (1990). Insect-Plant Interactions VII. Florida: CRC Press.

Bernays, E. A., and Chapman, R. F. (1994a). "Chemicals in plants," in HostPlant Selection by Phytophagous Insects, eds E. A. Bernays and R. F. Chapman (New York, NY: Chapman \& Hall), 14-60.

Bernays, E. A., and Chapman, R. F. (1994b). Host-Plant Selection by Phytophagous Insects. New York, NY: Chapman and Hall. doi: 10.1007/b102508

Bhowmik, D., Kumar, K. P. S., Paswan, S., and Srivastava, S. (2012). Tomato-a natural medicine and its health benefits. J. Pharmac. Phytochem. 1, 33-43.

\section{FUNDING}

Funding of this research was partly fulfilled by the following grants: the National Basic Research Program of China (973 Project No. 2013CB127600), National Natural Science Foundation of China (No. 31272089), and China Agriculture Research System (No. CARS-25-B-06)

\section{ACKNOWLEDGMENTS}

We greatly appreciate Prof. James Ridsdill-Smith (University of West Australia, Perth) for critical review and editing of this manuscript. Cordial thanks are expressed to N. Chen, Y.-H. Liu, and H.-H. Cao for their valuable technical instruction and data collection. We are glad for the support of all students and staff in the Key Laboratory of Applied Entomology, Northwest A\&F University at Yangling, Shaanxi, China.

\section{SUPPLEMENTARY MATERIAL}

The Supplementary Material for this article can be found online at: http://journal.frontiersin.org/article/10.3389/fpls.2017.00466/ full\#supplementary-material

Bleeker, P. M., Diergaarde, P. J., Ament, K., Guerra, J., Weidner, M., Schutz, S., et al. (2009). The role of specific tomato volatiles in tomato-whitefly interaction. Plant Physiol. 151, 925-935. doi: 10.1104/pp.109.142661

Blight, M. M., Le Metayer, M., Delegue, M. H. P., Pickett, J. A., Marion-Poll, F., and Wadhams, L. J. (1997). Identification of floral volatiles involved in recognition of oilseed rape flowers, Brassica napus by honeybees, Apis mellifera. J. Chem. Ecol. 23, 1715-1727. doi: 10.1023/B:JOEC.0000006446.21160.c1

Chau, A., Heinz, M., and Davies, F. T. Jr. (2005). Influences of fertilization on Aphis gossypii and insecticide usage. J. Appl. Entomol. 129, 89-97. doi: 10.1111/j.14390418.2005.00943.X

Chen, Y., Olson, D. M., and Ruberson, J. R. (2010). Effects of nitrogen fertilization on tritrophic interactions. Arthropod Plant Interact. 4, 81-94. doi: 10.1111/ 1744-7917.12123

Chen, Y., Ruberson, J. R., and Olson, D. M. (2008). Nitrogen fertilization rate affects larval performance and feeding, and oviposition preference of the beet armyworm, Spodoptera exigua, on cotton. Entomol. Exp. Appl. 126, 244-255. doi: 10.1111/j.1570-7458.2007.00662.x

Cook, S. M., Khan, Z. R., and Pickett, J. A. (2007a). The use of push-pull strategies in integrated pest management. Annu. Rev. Entomol. 52, 375-400.

Cook, S. M., Rasmussen, H. B., Birkett, M. A., Murray, D. A., Pye, B. J., Watts, N. P., et al. (2007b). Behavioural and chemical ecology underlying the success of turnip rape (Brassica napus) from the pollen beetle (Meligethes aeneus). Arthropod Plant Interact. 1, 57-67. doi: 10.1007/s11829-007-9004-5

Da Cruz, B. P., De Castro, E. M., Cardoso, M. D. G., De Souza, K. F., Machado, S. M. F., Pompeu, P. V., et al. (2014). Comparison of leaf anatomy and essential oils from Drimys brasiliensis Miers in a montane cloud forest in Itamonte, MG, Brazil. Bot. Stud. 55, 41. doi: 10.1186/s40529-014-0041-y

Das, P., Raina, R., Prasad, A., and Sen, A. (2007). Electroantennogram responses of the potato tuber moth, Phthorimaea operculella (Lepidoptera; Gelichiidae) to plant volatiles. J. Biosci. 32, 339-349. doi: 10.1007/s12038-0070033-0

Dicke, M., and Baldwin, I. T. (2010). The evolutionary context for herbivoreinduced plant volatiles: beyond the 'cry for help'. Trends Plant Sci. 15, 167-175. doi: 10.1016/j.tplants.2009.12.002 
Duffey, S. S., and Stout, M. J. (1996). Antinutritive and toxic components of plant defense against insects. Arch. Insect Biochem. Physiol. 32, 3-37. doi: 10.1002/ (SICI)1520-6327(1996)32:1<3::AID-ARCH2>3.0.CO;2-1

Egigu, M. C., Ibrahim, M. A., Riikonen, J., Yahya, A., Holopainen, T., Tiitto, R. J., et al. (2014). Effects of rising temperature on secondary compounds of yeheb (Cordeauxia edulis Hemsley). Am. J. Plant. Sci. 5, 517-527. doi: 10.4236/ajps. 2014.55066

Engel, E., Baty, C., Le Corre, D., Souchon, I., and Martin, N. (2002). Flavor active compounds potentially implicated in cooked cauliflower acceptance. J. Agric. Food Chem. 50, 6459-6467. doi: 10.1021/jf025579u

Engström, L., Stenberg, M., Aronsson, H., and Linden, B. (2011). Reducing nitrate leaching after winter oilseed rape and peas in mild and cold winters. Agron. Sustain. Dev. 31, 337-347. doi: 10.1051/agro/2010035

Fang, Y., Jiao, X., Xie, W., Wang, S., Wu, Q., Shi, X., et al. (2013). Tomato yellow leaf curl virus alters the host preferences of its vector Bemisia tabaci. Sci. Rep. 3:2876. doi: $10.1038 /$ srep02876

Finch, S. (1980). "Chemical attraction of plant-feeding insects to plants," in Applied Biology, ed. T. H. Coaker (New York, NY: Academic Press), 67-143.

Franco, C. R. P., Alves, P. B., Andrade, D. M., De Jesus, H. C. R., Silva, E. J. S., Santos, E. A. B., et al. (2011). Essential oil composition and variability in Hyptis fruticosa. Braz. J. Pharmacol. 21, 24-32. doi: 10.1002/ptr.3455

Fretz, T. A. (1976). Effect of photoperiod and nitrogen on the composition of foliar monoterpenes of Juniperus horizontalis Moench. cv Plumosa. J. Am. Soc. Hortic. Sci. 101, 611-613.

Frohlich, D. R., Torres, J. I., Bedford, I. D., Markham, P. G., and Brown, J. K. (1999). A phylogeographical analysis of Bemisia tabaci species complex based on mitochondrial DNA markers. Mol. Ecol. 8, 1683-1691. doi: 10.1046/j.1365294x.1999.00754.x

Germano, L. D. L., Picanço, M., Zanuncio, J. C., Moreira, M. D., and Jham, G. N. (2011). Hosting capacity of horticultural plants for insect pests in Brazil. Chil. J. Agric. Res. 71, 383-389. doi: 10.4067/S0718-58392011000300006

Gershenzon, J. (1994). Metabolic costs of terpenoid accumulation in higher plants. J. Chem. Ecol. 20, 1281-1321. doi: 10.1007/BF02059810

Gershenzon, J., and Croteau, R. (1991). “Terpenoids," in Herbivores: Their Interactions with Secondary Plant Metabolites, eds G. A. Rosenthal and M. R. Berembaum (Boca Raton, FL: CRC Press), 165-219. doi: 10.1016/B978-0-12597183-6.50010-3

Gonzales, W. L., Ramirez, C. C., Olea, N., and Niemeyer, H. M. (2002). Host plant changes produced by the aphid Sipha flava: consequences for aphid feeding behavior and growth. Entomol. Exp. Appl. 103, 107-113. doi: 10.1046/j.15707458.2002.00964.x

Gouinguenè, S., and Turlings, T. C. J. (2002). The effects of abiotic factors on induced volatile emission in corn plants. Plant Physiol. 129, 1296-1307. doi: 10.1104/pp.001941

Han, P., Lavoir, A. V., Bot, J. L., Desneux, E. A., and Desneux, N. (2014). Nitrogen and water availability to tomato plants triggers bottom-up effects on the leafminer, Tuta absoluta. Sci. Rep. 4:4455. doi: 10.1038/srep04455

Hasanuzzaman, A. T. M., Islam, M. N., Zhang, Y., Zhang, C.-Y., and Liu, T.X. (2016). Leaf morphological characters can be a factor for intra-varietal preference of whitefly Bemisia tabaci (Hemiptera:Aleyrodidae) among eggplant varieties. PLoS ONE 11:e0153880. doi: 10.1371/journal.pone.0153880

Herms, D. A., and Mattson, W. J. (1992). The dilemma of plants: to grow or defend. Q. Rev. Biol. 67, 283-335. doi: 10.1086/417659

Hognadottir, A., and Rouseff, R. L. (2003). Identification of aroma active compounds in orange essence oil using gas chromatography-olfactometry and gas chromatography-mass spectrometry. J. Chromatogr. A 998, 201-211. doi: 10.1016/S0021-9673(03)00524-7

Inbar, M., and Gerling, D. (2008). Plant-mediated interactions between whiteflies, herbivores, and natural enemies. Annu. Rev. Entomol. 53, 431-448. doi: 10.1146/annurev.ento.53.032107.122456

Jang, S., Hamayun, M., Sohn, E., Shin, D., Kim, K., Lee, B. M., et al. (2008). Effect of elevated nitrogen levels on endogenous gibberellin and jasmonic acid contents of three rice (Oryza sativa L.) cultivars. J. Plant Nutr. Soil Sci. 171, 181-186. doi: 10.1002/jpln.200625025

Jansen, R. M. C., Hofstee, J. W., Wildt, J., Verstappen, F. W. A., Bouwmeester, H. J., Posthumus, M. A., et al. (2008). Health monitoring of plants by their emitter volatiles: trichome damage and cell membrane damage are detectable at greenhouse scale. Ann. Appl. Biol. 154, 441-452. doi: 10.1111/j.1744-7348. 2008.00311.x

Jauset, A. M., Yokomi, R. K., Mayer, R. T., and Shapiro, J. P. (1995). Cytology and physiology of silverleaf whitefly-induced squash silverleaf. Exp. Appl. 46, 227-242.

Lange, W. H., and Bronson, L. (1981). Insect pests of tomato. Annu. Rev. Entomol. 26, 345-371. doi: 10.1146/annurev.en.26.010181.002021

Le Quere, J. L., and Latrasse, A. (1990). Composition of the essential oils of blackcurrant buds (Ribes nigrum L.). J. Agric. Food Chem. 38, 3-10. doi: 10.1021/ jf00091a001

Lee, K. D., Yang, M. S., Supanjani, and Smith, D. L. (2005). Fertilizer effect on the yield and terpene components from the flower heads of Chrysanthemum boreale M. (Compositae). Agron. Sustain. Dev. 25, 205-211. doi: 10.1051/agro:2005022

Li, T. Y., and Maschwitz, U. (1985). The sexual behavior of whitefly Trialeurodes vaporariorum. Acta Entomol. Sin. 28, 233-235.

Liu, T.-X. (2007). Life history of Eretmocerus melanoscutus (Hymenoptera: Aphelinidae) parasitizing nymphs of Bemisia tabaci biotype B (Homoptera: Aleyrodidae). Biol. Control 42, 77-85. doi: 10.1016/j.biocontrol.2007.03.008

Locascio, S. J., Clark, G. A., Czizinszky, A. A., Stanley, C. D., Olson, S. M., Rhoads, F. M., et al. (1992). Water and Nutrient Requirements for Drip-Irrigated Vegetables in Humid Regions. Gainesville, FL: University of Florida.

Luan, J. B., Yao, D. M., Zhang, T., Walling, L. L., Yang, M., Wang, Y. J., et al. (2013). Suppression of terpenoid synthesis in plants by a virus promotes its mutualism with vectors. Ecol. Lett. 16, 390-398. doi: 10.1111/ele.12055

Mattson, W. J. (1980). Herbivory in relation to plant nitrogen content. Annu. Rev. Ecol. Syst. 11, 19-61. doi: 10.1146/annurev.es.11.110180.001003

Mumm, R., and Dicke, M. (2010). Variation in natural plant products and the attraction of bodyguards for indirect plant defense. Can. J. Zool. 88, 628-667. doi: 10.1139/Z10-032

Nampoothiri, S. V., Venugopalan, V. V., Joy, B., Sreekumar, M. M., and Menon, A. N. (2012). Comparison of essential oil composition of three ginger cultivars from sub Himalayan region. Asia Pac. J. Trop. Biomed. 2, S1347-S1350. doi: 10.1016/s2221-1691(12)60414-6

Olaniyi, J. O., Akanbi, W. B., Adejumo, T. A., and Akande, O. G. (2010). Growth, fruit yield and nutritional quality of tomato varieties. Afr. J. Food Sci. 4, 398-402.

Olson, D. M., Cortesero, A. M., Rains, G. C., Potter, T., and Joe Lewis, W. (2009). Nitrogen and water affect direct and indirect plant systemic induced defense in cotton. Biol. Control. 49, 239-244. doi: 10.1016/j.biocontrol.2009.02.011

Owolabi, M. S., Oladimeji, M. O., Labunmi, L., Singh, G., Marimuthu, P., and Valery, A. I. (2007). Composition and biological potentials of the essential oil of Zingiber officinale (Roscoe) from Nigeria. Bull. Pure Appl. Sci. 26, 113-119.

Raguso, R. A., Light, D. M., and Pickersky, E. (1996). Electroantennogram responses of Hyles lineata (Sphingidae: Lepidoptera) to volatile compounds from Clarkia breweri (Onagraceae) and other moth- pollinated flowers. J. Chem. Ecol. 22, 1735-1766. doi: 10.1007/BF02028502

Reddy, A. S., and Rao, V. N. (1989). Cotton whitefly (Bemisia tabaci Genn.) A review. Indian J. Plant Protec. 17, 171-179.

Saad, K. A., Roff, M. N. M., Hallett, R. H., and Idris, A. B. (2015). Aphid-induced defenses in chilli affect preferences of the whitefly, Bemisia tabaci (Hemiptera: Aleyrodidae). Sci. Rep. 5:13697. doi: 10.1038/srep13697

Saad, K. A., Roff, M. N. M., Shukri, M. A. M., Mirad, R., Mansour, S. A. A., Abuzid, I., et al. (2013). Behavioral responses of whitefly, Bemisia tabaci (Hemiptera: Aleyrodidae), in relation to sex and infestation status of their host plants. Acad. J. Entomol. 6, 95-99.

Sa-Nguanpuag, K., Kanlayanarat, S., Srilaong, V., Tanprasert, K., and Techavuthiporn, C. (2011). Ginger (Zingiber officinale) oil as an antimicrobial agent for minimally processed produce: a case study in shredded green papaya. Int. J. Agric. Biol. 13, 895-901.

Schoonhoven, L. M., Vanloon, J. J. A., and Dicke, M. (2005). Insect-Plant Biology. Oxford: Oxford University Press.

Sieling, K., and Kage, H. (2010). Efficient N management using winter oilseed rape. A review. Agron. Sustain. Dev. 30, 271-279. doi: 10.1051/agro/2009036

Simmons, A. M., and Gurr, G. M. (2005). Trichomes of Lycopersicon species and their hybrids: effects on pests and natural enemies. Agric. For. Entomol. 7, 265-276. doi: 10.1111/j.1461-9555.2005.00271.x 
Simpson, S. J., and Simpson, C. L. (1990). "The mechanisms of nutritional compensation by phytophagous insects," in Insect-Plant Interactions, Vol. II, ed. E. A. Bernays (Boca Raton, FL: CPC Press), 111-160.

Slosser, J. E., Parajulee, M. N., Hendrix, D. L., Henneberry, T. J., and Pinchak, W. E. (2004). Cotton aphid (Homoptera: Aphididae) abundance in relation to cotton leaf sugars. Environ. Entomol. 33, 690-699. doi: 10.1603/0046-225X-33. 3.690

Southwood, T. R. E. (1973). "The insect/plant relationship-an evolutionary perspective," in Insect-plant Relationship, Vol. 6, ed. F. V. Emden (London: Symp. Royal Entomol. Soc), 3-30.

Stout, M. J., Brovont, R. A., and Duffey, S. S. (1998). Effects of nitrogen availability on expression of constitutive and inducible chemical defenses in tomato. J. Chem. Ecol. 24, 945-963. doi: 10.1023/A:1022350 100718

Szendrei, Z., and Rodriguèz-Saona, C. A. (2010). A meta-analysis of insect pest behavioural manipulation with plant volatiles. Entomol. Exp. Appl. 134, 201-210. doi: 10.1111/j.1570-7458.2009.00954.x

Toscano, L. C., Boica, A. L., and Maruyama, W. I. (2002). Non-preference of whitefly for oviposition in tomato genotypes. Sci. Agric. 59, 677-681. doi: 10.1590/S0103-90162002000400009

Tuomi, J., Niemela, P., Haukioja, E., Siren, S., and Neuvonen, S. (1994). Nutrient stress: an explanation for plant anti-herbivore responses to defoliation. Oecologia 61, 208-210. doi: 10.1007/BF00396762

Ukeh, D. A., Birkett, M. A., Pickett, J. A., Bowman, A. S., and Mordue Luntz, A. J. (2009). Repellent activity of alligator pepper, Aframomum melegueta, and ginger, Zingiber officinale, against the maize weevil, Sitophilus zeamais. Phytochemistry 70, 751-758. doi: 10.1016/j.phytochem.2009. 03.012

Unsicker, S. B., Kunert, G., and Gershenzon, J. (2009). Protective perfumes: the role of vegetative volatiles in plant defense against herbivores. Curr. Opin. Plant Biol. 12, 479-485. doi: 10.1016/j.pbi.2009.04.001

Van Den Dool, H., and Kratz, P. D. J. A. (1963). A generalization of the retention index system including linear temperature programmed gas-liquid partition chromatography. J. Chromatogr. 11, 463-471. doi: 10.1016/S0021-9673(01) 80947-X

Van Wassenhove, F. A., Dirinck, P. J., Schamp, N. M., and Vulsteke, G. A. (1990). Effect of nitrogen fertilizers on celery volatiles. J. Agric. Food Chem. 38, 220-226. doi: 10.1021/jf00091a049

Veromann, E., Toome, M., Kännaste, A., Kaasik, R., Copolovici, L., Flink, J., et al. (2013). Effects of nitrogen fertilization on insect pests, their parasitoids, plant diseases and volatile organic compounds in Brassica napus. Crop. Prot. 43, 79-88. doi: 10.1016/j.cropro.2012.09.001

Wahle, E. A., and Masiunas, J. B. (2003). Population density and nitrogen fertility effects on tomato growth and yield. Hort. Sci. 38, 367-372.

Wang, Y. T., Huang, S. W., Liu, R. L., and Jin, J. Y. (2007). Effects of nitrogen application on flavor compounds of cherry tomato fruits. J. Plant Nutr. Soil Sci. 170, 1-8. doi: 10.1002/jpln.200700011
Warneke, C., Van der Veen, C., Luxembourg, S. L., de Gouw, J. A., and Kok, A. (2001). Measurements of benzene and toluene in ambient air using protontransfer-reaction massspectrometry: calibration, humidity dependence and field intercomparison. Int. J. Mass Spectrom. 207, 167-182. doi: 10.1016/S13873806(01)00366-9

Yang, N. W., Li, A. L., Wan, F. H., Liu, W. X., and Johnson, D. (2010). Effects of plant essential oils on immature and adult sweetpotato whitefly, Bemisia tabaci biotype B. Crop Prot. 29, 1200-1207. doi: 10.1016/j.cropro.2010.05.006

Ying, J., Huang, J., Rui-yan, M., and Ju-cai, H. (2003). Host plant preferences of Bemisia tabaci Gennadius. Insect Sci. 10, 109-114. doi: 10.1111/j.1744-7917. 2003.tb00372.x

Zaini, M. R., Rawi, C. S. M., and Hassan, A. (2013). Effect of nutrient and preinfested brinjal, Solanum melongena by whitefly and aphid on population dynamics of whitefly, Bemisia tabaci. Agric. For. Fish. 2, 1-10. doi: 10.11648/ j.aff.20130201.11

Zhang, A., Linn, C., Wright, S., Prokopy, R., Reissig, W., and Roelofs, W. (1999). Identification of a new blend of apple volatiles attractive to the apple maggot, Rhagoletis pomonella. J. Chem. Ecol. 25, 1221-1232. doi: 10.1007/BF00989104

Zhang, W., McAuslane, H. J., and Schuster, D. J. (2004). Repellency of ginger oil to Bemisia argentifolii (Homoptera: Aleyrodidae) on tomato. J. Econ. Entomol. 97, 1310-1318. doi: 10.1093/jee/97.4.1310

Zheng, L. X., Wu, W. J., Liang, G. W., and Fu, Y. G. (2013). 3,3-dimethyl-1butanol, a parakairomone component to Aleurodicus dispersus (Hemiptera: Aleyrodidae). Arthropod Plant Interact. 7, 423-429. doi: 10.1007/s11829-0139258-Z

Zotarelli, L., Scholberg, J. M., Dukes, M. D., and Carpena, R. M. (2007). Monitoring of nitrate leaching in sandy soils: comparison of three methods. J. Environ. Qual. 36, 953-962. doi: 10.2134/jeq2006.0292

$\mathrm{Zu}$ Dohna, H. (2006). The distribution of eggs per host in a herbivorous insectintersection of oviposition, dispersal and population dynamics. J. Anim. Ecol. 75, 387-395. doi: 10.1111/j.1365-2656.2006.01059.x

Conflict of Interest Statement: The authors declare that the research was conducted in the absence of any commercial or financial relationships that could be construed as a potential conflict of interest.

The reviewer SG and handling Editor declared their shared affiliation, and the handling Editor states that the process nevertheless met the standards of a fair and objective review.

Copyright (c) 2017 Islam, Hasanuzzaman, Zhang, Zhang and Liu. This is an openaccess article distributed under the terms of the Creative Commons Attribution License (CC BY). The use, distribution or reproduction in other forums is permitted, provided the original author(s) or licensor are credited and that the original publication in this journal is cited, in accordance with accepted academic practice. No use, distribution or reproduction is permitted which does not comply with these terms. 